\title{
Intra-site Obsidian Subsource Patterns at Contraguda, Sardinia (Italy)
}

\author{
R.H. Tykot, L. Lai, and C. Tozzi
}

\section{Introduction}

Obsidian sourcing studies have been done in the Mediterranean for more than 40 years, while in the last decade the importance of attributing artifacts to specific subsources has been demonstrated, as it reveals geographic and chronological patterns of obsidian usage. In particular, changes in the usage of the Monte Arci (Sardinia) subsources have raised questions about quality, quantity, access, and socioeconomic factors involved in the acquisition, production, trade, and use of obsidian during the Early, Middle, and Late Neolithic periods (ca. 6000-3000 BC).

In this study, nearly 250 obsidian artifacts from the Late Neolithic site of Contraguda in northern Sardinia were chemically analyzed by LA-ICP-MS and pXRF and attributed to specific Monte Arci subsources. This large number of analyses, at present the most done for a single site in Sardinia or Corsica, allows testing for subsource usage patterns from different contexts within the site, and provides some interpretations about obsidian selection and use.

\section{Contraguda}

The open-air site of Contraguda sits on a hill in the Coghinas Valley of northern Sardinia (Fig. 1). Used during the Late Neolithic, or the Ozieri period, this site extends over several hectares and is the largest Ozieri settlement known on Sardinia. Not only is the site one of the largest open-air sites from this time, but it is also one of the only open-air sites with obsidian artifacts.

This site was identified in 1980 during an archaeological survey that was conducted to identify and catalog archaeological features in the region. In 1992,

\author{
R.H. Tykot $(\bowtie)$ and L. Lai \\ Department of Anthropology, University of South Florida, Tampa, FL 33620, USA \\ e-mail: rtykot@cas.usf.edu \\ C. Tozzi \\ Dipartimento di Scienze Archeologiche, Università di Pisa, 56126 Pisa, Italy
}



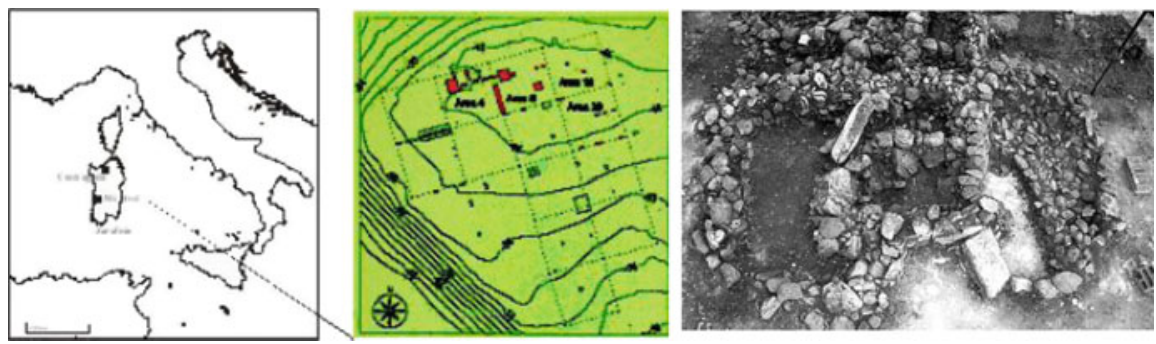

Fig. 1 Regional map showing location of Contraguda in northern Sardinia (left); detailed grid map showing the open-air archaeological site and the areas with obsidian artifacts tested (center); and a photograph of Structure A-B (right)

Boschian et al. (2000-2001) conducted a systematic investigation of Contraguda, with radiocarbon dates placing it in the fourth millennium BC, ca. 4050-3770 BC. The context of the obsidian tools are mainly later in the Ozieri period. Much of the obsidian was found outside of a feature, called Structure A-B, composed of a series of small, interrelated walls, which are of unknown function.

\section{Monte Arci Obsidian}

Previous work has identified many obsidian subsources on Monte Arci, with differences in their quantity, quality, and accessibility, while these subsources may be chemically distinguished using a variety of analytical methods (Tykot 1997; 2002). Chronological changes in the usage of the respective subsources has also been demonstrated for many sites in Sardinia and Corsica (Tykot 1996; 2004).

The main subsources are identified as SA, SB1, SB2, and SC, while SB1 and SC may be further subdivided into further subgroups. The SA and SB2 subsources, located on the southwest and west side of Monte Arci, respectively, have the glassiest, most transparent obsidian; the SC subsource is located on the northeast side of Monte Arci, is opaque and less brittle than the SA and SB2 obsidian, and appears to have been the major subsource used in the Late Neolithic. Type SB1 obsidian, from the west-central part of Monte Arci, was rarely used in any time period, most likely because it exists only in modest quantities and in small blocks. Besides primary source localities, it is also important to note that unworked raw material may be found in secondary natural deposits, especially SC obsidian to the south of Monte Arci (Lugliè et al. 2006).

\section{Analytical Methods and Results}

For the Contraguda project, samples were initially categorized based on visual examination and density testing. This was followed by trace element analyses on a mostly random selection of 93 artifacts using laser ablation inductively coupled 


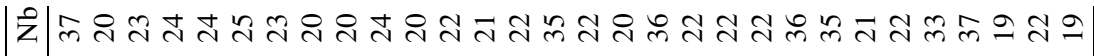
ஸे 入

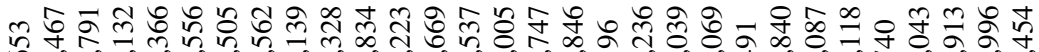
$\infty$ I

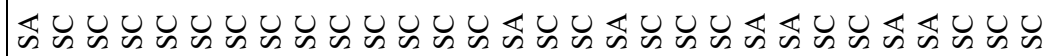

तூ

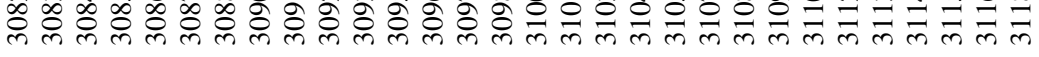
๓ீत्ป

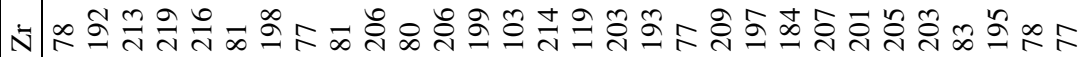

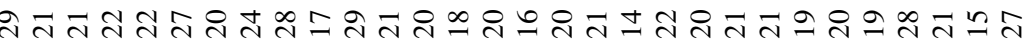

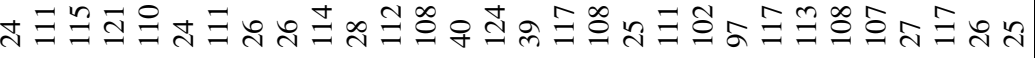

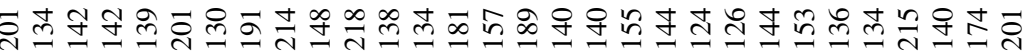

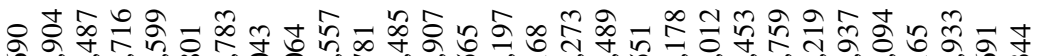

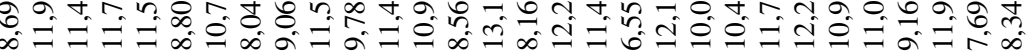

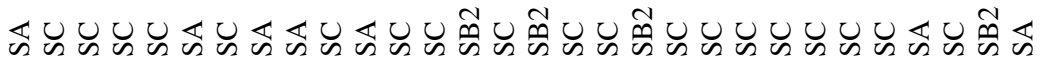
苦文응 mீ

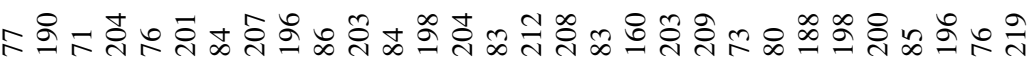
ปิ

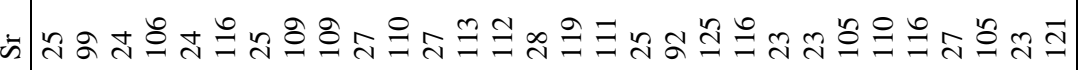

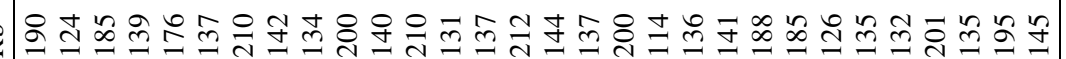

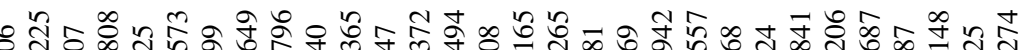
$\infty 0$ 年 


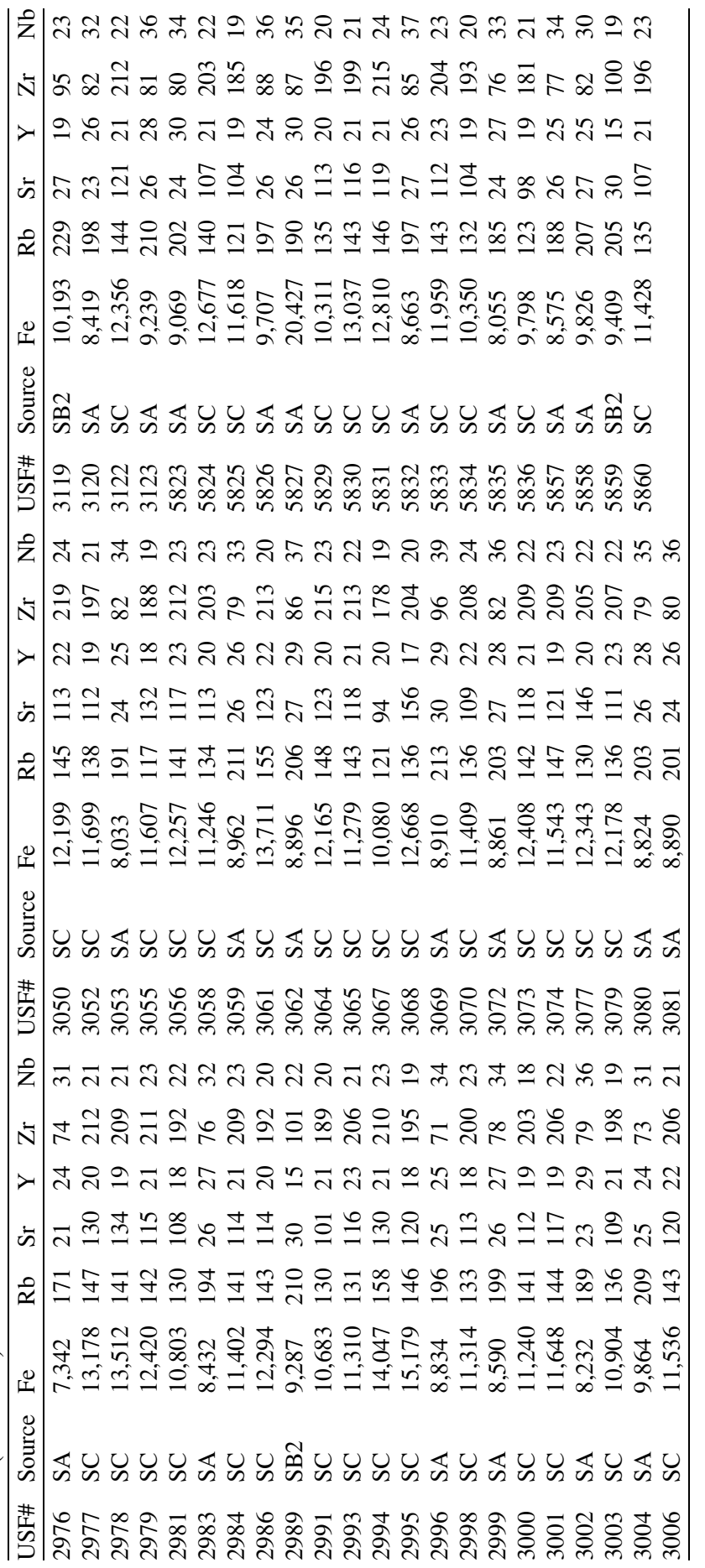


plasma mass spectrometry (LA-ICP-MS), at the University of Missouri Research Reactor (Lai et al. 2006; Speakman et al. 2007).

In this study, an additional 155 artifacts were tested using a Bruker Tracer III-V portable X-ray fluorescence spectrometer. This instrument, which is entirely nondestructive, was previously tested on geological samples to demonstrate that it could differentiate all of the Mediterranean sources and subsources. A specific "obsidian" filter $(12 \mathrm{mil} \mathrm{Al}+1 \mathrm{mil} \mathrm{Ti}+6 \mathrm{mil} \mathrm{Cu})$ was used to enhance results for certain elements known to be useful for sourcing obsidian, while the analysis settings chosen were $40.00 \mathrm{kV}, 10.00 \mu \mathrm{A}$, and $300 \mathrm{~s}$. The results were calibrated against known obsidian samples used in multiple laboratories, including the Missouri University Research Reactor and the Smithsonian Institution (Table 1). Geological samples from all of the Monte Arci subsources were also tested with the exact same instrument.

It is fairly straightforward to distinguish chemically between the Monte Arci subsources, by LA-ICP-MS and pXRF, using simple X-Y plots of a few elements (Fig. 2).

The results clearly indicate that type SC obsidian is the most represented, while type SB2 is barely present (seven samples), and thus match with studies done for other Late Neolithic sites in Sardinia and Corsica (Fig. 3).

\section{Discussion}

The study of such a large collection of obsidian artifacts at the open-air Late Neolithic site of Contraguda is significant both for the methodological approaches used, which are non-destructive and of modest cost, and for the archaeological

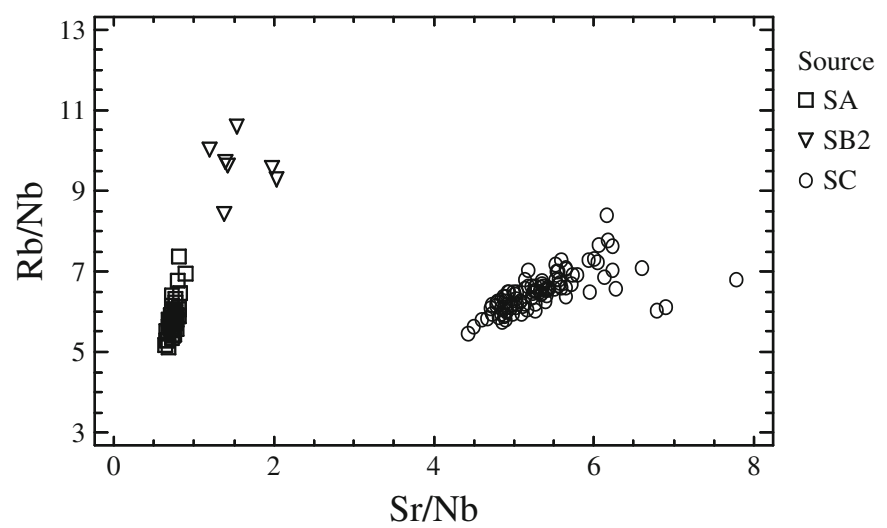

Fig. 2 Simple $\mathrm{X}-\mathrm{Y}$ plot of rubidium/niobium $(\mathrm{Rb} / \mathrm{Nb})$ vs. strontium/niobium $(\mathrm{Sr} / \mathrm{Nb})$ for all of the Contraguda obsidian artifacts tested by pXRF, distinguishing between the three Monte Arci obsidian subsources (SA, SB2, SC) 


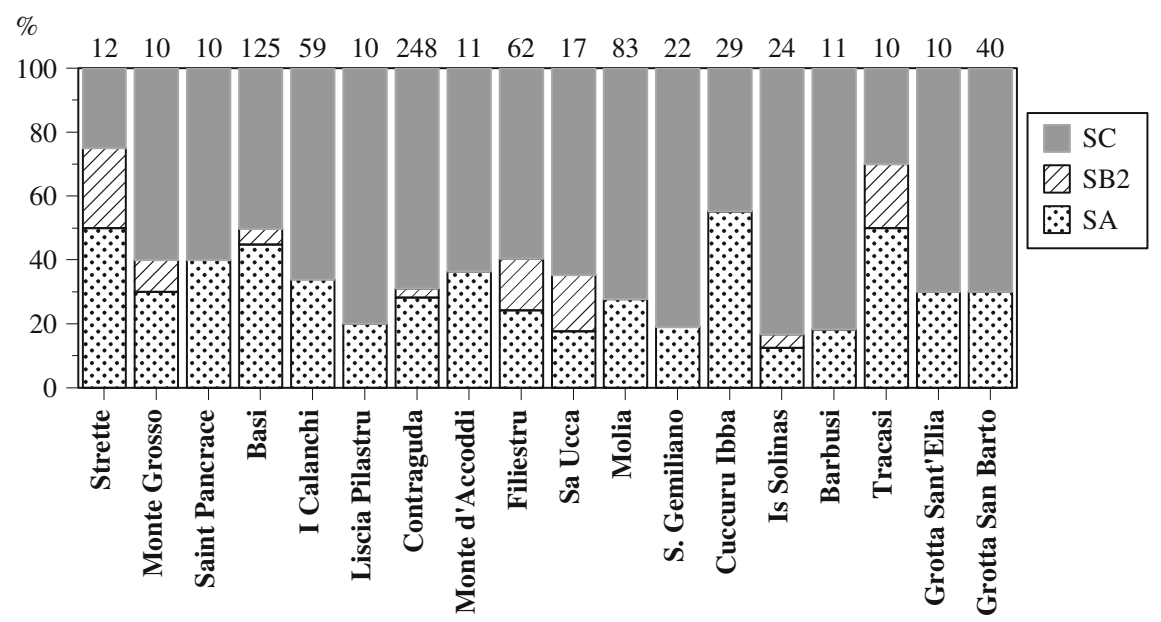

Fig. 3 Monte Arci subsource frequency at Late Neolithic sites in Corsica and Sardinia with ten or more chemical analyses done (number of samples on top of each bar)
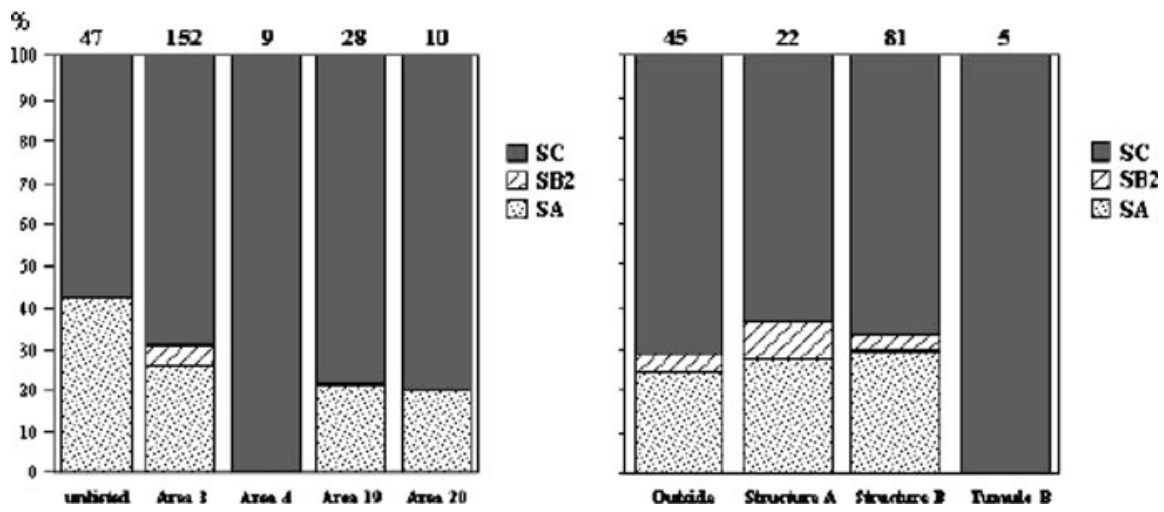

Fig. 4 Comparison of obsidian subsources present in different areas of the Contraguda site (left), and within Area 3 (right). The number of samples tested is at the top of each bar

significance of the findings. First, it is clear that a statistically significant number of samples should always be tested in order to reveal any patterns in obsidian acquisition, use, and discard. Use-wear studies on many of the obsidian samples tested already suggest that type SC obsidian was used for processing more hard inorganic materials than type SA, while SA was used to process more medium hard inorganic materials (Setzer et al. 2004). It has also been shown that density measurements and visual examination by experienced individuals can potentially provide a reasonable overview of Monte Arci obsidian subsource usage, especially the percentages of the SA and SC subsources. More significantly, the analysis of obsidian artifacts from different areas of the Contraguda site show some variation in subsource usage (Fig. 4). While the 47 general finds (from 
localities outside Areas 3, 4, 19 and 20) from the site are approximately 42\% SA and $58 \% \mathrm{SC}$, the four excavated Areas have much greater percentages of SC, especially Area 4 (albeit only nine artifacts tested).

The importance of selecting samples from specific site features is quite clear when we focus on Area 3, where there is the one structure found at Contraguda. Within Area 3, at the tumulus, there is a modest cluster (five pieces) of entirely type SC obsidian, comparable to the similar cluster in Area 4, while found within the other parts of Area 3 were all of the SB2 obsidian artifacts. The proportions of SA and SC are quite similar between all parts of Area 3 except for the tumulus, and have more SA represented than in Areas 19 and 20.

\section{Conclusion}

The analyses of such a large number of artifacts from specific contexts at a single site provide statistically significant data about obsidian subsource selection and use, which may be combined with lithic technology, use-wear studies, and other contextual information to reconstruct the chaîne opératoire for this important period in Sardinian prehistory. This type of detailed sourcing study, using non-destructive portable XRF analysis, may also make major contributions in other areas of Italy and beyond.

\section{References}

Boschian G, Brilli P, Falchi P, Fenu P, Martini F, Pitzalis G, Sarti L, Tozzi C (2000-2001) Prime ricerche nell'abitato neolitico di Contraguda (Perfugas, Sassari). Rivista di Scienze Preistoriche 51:235-287

Lai L, Tykot RH, Tozzi C (2006) Nuovi risultati sulla provenienza dell'ossidiana del sito neolitico recente di Contraguda (Sardegna). Atti del XXXIX Riunione Scientifica dell'Istituto Italiano di Preistoria e Protostoria: Materie prime e scambi nella preistoria italiana, Firenze, 25-27 Nov 2004, pp 598-602

Lugliè C, Le Bourdonnec F-X, Poupeau G, Bohn M, Meloni S, Oddone M, Tanda G (2006) A Map of the Monte Arci (Sardinia Island, Western Mediterranean) Obsidian Primary to Secondary Sources. Implications for Neolithic Provenance Studies. C R Palevol 5:995-1003

Setzer TJ, Tykot RH, Tozzi C (2004) Combining Obsidian Provenance and Use-wear Studies: an analysis of artifacts from the Late Neolithic Site of Contraguda, Sardinia. 34th international symposium on Archaeometry. Zaragoza, Spain, May 3-7

Speakman RJ, Glascock MD, Tykot RH, Descantes C, Thatcher JJ, Skinner CE, Lienhop KM (2007) Selected applications of Laser Ablation Inductively Coupled Plasma-Mass Spectrometry Archaeological Research. In: Glascock MD, Speakman RJ, Popelka-Filcoff RS (eds) Archaeological chemistry: analytical techniques and archaeological interpretation, American chemical society symposium series. 968, Washington, DC, pp 275-296

Tykot RH (1996) Obsidian procurement and distribution in the Central and Western Mediterranean. J Mediterranean Archaeol 9(1):39-82 
Tykot RH (1997) Characterization of the Monte Arci (Sardinia) Obsidian Sources. J Archaeol Sci 24:467-479

Tykot RH (2002) Chemical fingerprinting and source-tracing of Obsidian: the Central Mediterranean trade in Black Gold. Acc Chem Res 35:618-627

Tykot RH (2004) L'esatta provenienza dell'ossidiana e i modelli di diffusione nel Mediterraneo centrale durante il Neolitico. In: Castelli P, Cauli B, Di Gregorio F, Lugliè C, Tanda G, Usai C (eds) L'ossidiana del Monte Arci nel Mediterraneo: recupero dei valori di un territorio. Tipografia Ghilarzese, Ghilarza, pp 118-132 